\title{
APPLICATION OF THE TAGUCHI METHOD TO OPTIMIZE THE CUTTING CONDITIONS IN HARD TURNING OF A RING BORE
}

\author{
UPORABA TAGUCHI-JEVE METODE ZA OPTIMIZACIJO TRDEGA \\ STRUŽENJA ROBA IZVRTINE
}

\author{
Mehmet Boy ${ }^{1}$, Ibrahim Ciftci ${ }^{2}$, Mustafa Gunay ${ }^{3}$, Feridun Ozhan ${ }^{4}$ \\ ${ }^{1}$ Karabuk Vocational College, Karabuk University, Karabuk, Turkey \\ ${ }^{2}$ Department of Manufacturing Engineering, Karabuk University, Karabuk, Turkey \\ ${ }^{3}$ Department of Mechanical Engineering, Karabuk University, Karabuk, Turkey \\ ${ }^{4}$ ORS Bearing, Ankara, Turkey \\ mboy@karabuk.edu.tr \\ Prejem rokopisa - received: 2014-09-29; sprejem za objavo - accepted for publication: 2014-11-28
}

doi:10.17222/mit.2014.246

\begin{abstract}
This paper is focused on optimizing the cutting conditions for the surface roughness, inner-diameter error and roundness obtained in hard turning of an inner ring bore. The hard-turning experiments were conducted on hardened and tempered AISI 52100 bearing rings using the L9 orthogonal array on a CNC lathe. The cutting speed, feed rate and number of the machined part were selected as control factors. The optimum cutting conditions were determined using the signal-to-noise $(S / N)$ ratio. $S / N$ ratios were calculated using the lower-the-better approach. An analysis of variance (ANOVA) was also employed to determine the level of the effect of the control factors for the surface roughness, inner-diameter error and roundness. The statistical analysis showed that the feed rate was the most significant factor for the surface roughness while the cutting speed was the most significant factor for the roundness and inner-diameter error. Finally, the optimum cutting conditions were further confirmed with confirmation tests.

Keywords: diameter error, hard turning, roundness, surface roughness, Taguchi method
\end{abstract}

Članek je osredinjen na optimiranje razmer pri rezanju glede na hrapavost površine, napake notranjega premera in okroglosti pri trdem struženju notranjega roba izvrtine. Preizkusi trdega struženja so bili izvršeni pri kaljenem in popuščenem AISI 52100 obroču ležaja z uporabo L9 ortogonalne matrike na CNC-stružnici. Hitrost rezanja, hitrost podajanja in število obdelanih kosov so bili izbrani kot kontrolni faktorji. Optimalne razmere rezanja so bile izbrane z uporabo razmerja signal-hrup $(S / N)$. $S / N$-razmerja so bila izračunana s približkom čim manj tem boljše. Analiza variance (ANOVA) je bila tudi uporabljena za določitev vpliva kontrolnih faktorjev na hrapavost površine, napak notranjega premera in okroglosti. Končno so bili optimalni parametri potrjeni s potrditvenimi preizkusi.

Ključne besede: napaka premera, trdo struženje, okroglost, hrapavost površine, Taguchi-jeva metoda

\section{INTRODUCTION}

Bearings are the most important components of rotating mechanical systems. The highly precise surface finish, material properties, cleanliness, dimensions and tolerances of today's bearings contribute significantly to the product performance. Traditionally, bearing rings are manufactured from the soft AISI 52100 steel through forging, cold ring rolling and machining processes to their near-net shapes. Then, they are hardened and tempered to obtain the required hardness. The final geometry and surface quality are achieved through grinding and super-finishing processes. The hard-turning process has been increasingly used as an alternative to grinding operations. The hard-turning process has the capacity of machining the hardened components such as roller bearings, gears, shafts, cams, axles requiring a low surface roughness and close dimensional and form tolerances. Hard turning, compared to grinding operations, has many advantages such as a high material-removal rate, lower production costs, a shorter cycle time, an improved overall product quality, and a lower environmental impact. However, in the area of precision hard turning, due to the demands for a geometric accuracy of a few micrometers, its application is limited by the uncertainties with respect to the part quality and process reliability. ${ }^{1-4}$

For a turned part, the diameter error, the surface roughness and the roundness are the three most important quality characteristics. There are many causes for dimensional and geometric accuracy errors in hard turning. The roundness error is considered to be one of the important geometrical errors of cylindrical components because it has a negative effect on the accuracy and other important factors such as the mating mechanical components and wear of rotating elements. ${ }^{5,6}$

The machine-tool rigidity and clamping system influence the form accuracy and dimensional tolerance in precision hard turning. Possible machining errors may be caused due to different types of clamping, the number of clamping jaws, clamping forces, the hydraulic pressure of a clamping system, the clamping rigidity and accuracy. The effects of clamping techniques on the deformations of thin-walled rings have been investigated by many researchers. ${ }^{7-13}$ 
Geometric errors mostly result from the inaccuracy of tooling parts, such as inserts, tool holders and clamping devices. ${ }^{12}$ An investigation suggested that after replacing an insert, the repeatability errors at the tip of the insert can reach up to several microns, and the displacement of a tool tip under a cutting load can also reach several microns. Precision hard turning requires highly precise machine tools to eliminate the form and dimensional errors induced by the moving components of a machine tool such as the spindle, the slide bed and the tail stock. ${ }^{7-13}$

The surface roughness is one of the most important requirements in a machining process, as it is considered to be an indicator of the product quality. It indicates the irregularities of a surface texture. Achieving a desired surface quality is critical for the functional behavior of a part. The surface roughness influences the performance of mechanical parts and their production costs because it affects the factors such as friction, ease of holding the lubricant, electrical and thermal conductivities. A relatively better surface finish may involve a higher cost of manufacturing. The surface roughness and the roundness error are affected by several factors including the cutting-tool geometry, the cutting speed, the feed rate, the microstructure of a workpiece and the rigidity of a machine tool. ${ }^{14,15}$

In recent years, much work has been performed using various statistical and experimental techniques. These studies were mostly based on the design and analysis of experimental methods to determine the effects of the cutting parameters on the diameter error, the roundness and the surface roughness of cylindrical parts. Islam ${ }^{5}$ investigated the effects of the cooling method, the blank size and the work material on the dimensional accuracy and surface finish of various turning parts using the traditional analysis, Pareto ANOVA and the Taguchi method. The results showed that the work material had the greatest effect on the diameter error and surface roughness, while the major contributor to the circularity was the blank size. Rafai and Islam ${ }^{6}$ experimentally and analytically investigated the effects of the cutting parameters on the dimensional accuracy and surface finish in dry turning. The Taguchi method and the Pareto ANOVA analysis were used to determine the effects of the major controllable machining parameters and, subsequently, to find their optimum combination. They reported that while the surface roughness could be optimized through a proper selection of the feed rate, optimization of the diameter error and circularity was difficult due to the complex interactions between the input parameters. Brinksmeier et $\mathrm{al}^{8}{ }^{8}$ analyzed the basic mechanisms causing a ring distortion in soft machining in order to derive the strategies for its minimization. They concluded that distortion was significantly influenced by the turning before the heat treatment in the manufacture of bearing rings and that the elastic ring deformation under the clamping force led to variations in the depth of cut and polygonal form. Brinksmeier and Sölter ${ }^{10}$ developed a new method to predict the shape deviation of machined workpieces with a complex geometry. This new method combined the experimental results for the machining workpieces with simple geometries using finite-element simulations. This was achieved by making use of the known source stresses in simple parts for which the approach was validated. Finally, the method was applied to predict the shape deviation of a ground linear rail guide. Zhou et al. ${ }^{12}$ analyzed the possible error-driver factors and error sources in the precision hard turning and a strategy was proposed for an on-line compensation of dimensional errors, based on the tool-wear monitoring and a thermal-expansion prediction. They found that within a certain range of flank wear, the developed method could significantly improve the geometric accuracy. Sölter et al. ${ }^{13}$ analyzed the strategies for reducing the roundness deviations of turned rings using a three-jaw chuck. The simulations and measurements agreed reasonably well and showed that the minimum out-of-roundness strongly depends on the interaction of the angular shift between the external and internal clamping with the deviation between the segment-jaw diameter and the inner-ring diameter.

The purpose of this study was to obtain the optimum cutting conditions (the cutting speed, the feed rate, the number of the machined part) for minimizing the surface roughness, diameter error and roundness when hard turning an inner-bearing ring bore. An L9 orthogonal array was used in the design of the experiment. The Taguchi method and an analysis of variance (ANOVA) were also used to achieve this purpose. Furthermore, ANOVA was used to determine the statistical significance of the cutting conditions. In addition, the optimum cutting conditions were aimed to be further confirmed by confirmation tests.

\section{MATERIAL AND METHOD}

\subsection{Material}

The hard turning tests were performed on the inner bearing ring bores of AISI 52100 steel, the composition of which is given in Table 1. The geometry of the inner-bearing ring is given in Figure 1. The rings were manufactured from soft AISI 52100 through forging, spheroidising, cold ring rolling, soft machining, hardening and, finally, tempering processes to their near-net shapes. The rings were hardened and tempered to $58-62$ HRc.

Table 1: Chemical composition of AISI 52100 steel (w/\%)

Tabela 1: Kemijska sestava jekla AISI $52100(w / \%)$

\begin{tabular}{|c|c|c|c|c|c|c|c|c|c|}
\hline $\mathrm{C}$ & $\mathrm{Si}$ & $\mathrm{Mn}$ & $\mathrm{P}$ & $\mathrm{Ni}$ & $\mathrm{Cr}$ & $\mathrm{Mo}$ & $\mathrm{Cu}$ & $\mathrm{Al}$ & $\mathrm{Fe}$ \\
\hline
\end{tabular}

\begin{tabular}{|l|l|l|l|l|l|l|l|l|l|}
\hline 0.99 & 0.24 & 0.36 & 0.016 & 0.06 & 1.43 & 0.02 & 0.10 & 0.017 & Balance \\
\hline
\end{tabular}

\subsection{Cutting inserts and the tool holder}

The cutting tools used were commercial-grade TiN-coated low-content CBN inserts with the geometry of DCGW 11T304 produced by Sandvik Coromant. 


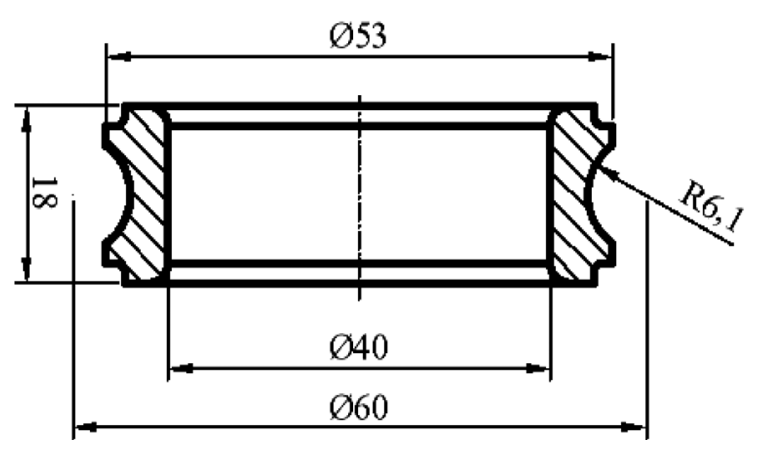

Figure 1: Geometry of the inner ring used for hard-turning tests Slika 1: Geometrija notranjega obroča, uporabljenega pri preizkusih trdega struženja

These inserts were recommended for machining hardened steel by Sandvik and had the 7015 Sandvik designation. The inserts were rigidly mounted on a righthand-style tool holder designated by ISO as A25T SDUCR 11 for hard turning inner ring bores.

\subsection{Cutting conditions and measurements}

The hard-turning tests were carried out on a twinspindle CNC chucker equipped with a pair of highly precise collet chucks. Three cutting speeds (120, 140 and $160) \mathrm{m} / \mathrm{min}$ and three feed rates $(0.04,0.06$ and 0.08 ) $\mathrm{mm} / \mathrm{r}$ with a fixed depth of cut of $50 \mu \mathrm{m}$ were tested. At each condition, a total of 12 rings were hard turned. Surface-roughness and roundness measurements were carried out on the hard-turned bore surfaces using a Taylor Hobson precision instrument. The inner diameter of an inner ring bore was measured with Diatest UD-1. The surface-roughness, roundness and diameter-error measurements were carried out on the $4^{\text {th }}, 8^{\text {th }}$ and $12^{\text {th }}$ hard-turned rings and the readings were averaged.

\subsection{Design and analysis of the experiments}

Optimization of machining processes is essential for achieving a high responsiveness to production, which provides a preliminary basis for the survival in today's dynamic market conditions. The Taguchi method is widely used in engineering analyses and it is a powerful design tool. This method dramatically reduces the number of tests using orthogonal arrays and minimizes the effects of the factors that cannot be controlled. Furthermore, it provides a simple, efficient and systematic approach to specifying the optimum cutting parameters for a manufacturing process. ${ }^{16,17}$

The Taguchi method converts objective function values to the signal-to-noise $(S / N)$ ratio to measure the performance characteristics at the levels of the control factors against these factors. The $S / N$ ratio is defined as the desired signal ratio for an undesired random-noise value and shows the quality characteristics of the experimental data. ${ }^{16,17}$ Usually, there are three categories of the performance characteristic in an analysis of the $S / N$ ratio, i.e., the lower-the-better, the higher-the-better and the nominal-the-better characteristics. The goal of this study was to minimize the surface roughness, the innerdiameter error and the roundness. Therefore, the lowerthe-better quality characteristic was used as shown in Equation (1):

$$
\frac{S}{N(\eta)}=-10 \cdot \lg \left[\frac{1}{n} \cdot \sum_{i=1}^{0} Y_{i}^{2}\right]
$$

where $Y_{i}$ is the observed data during the experiment and $n$ is the number of experiments. ${ }^{16,17}$

In this study, the cutting speed $(V)$, the feed rate $(f)$ and the number of the machined part $(M P)$ were selected as the control factors and their levels were determined as shown in Table 2. The L9 orthogonal array of the Taguchi method allowed us to determine the optimum cutting conditions and analyze the effects of the machining parameters.

Table 2: Control factors and their levels

Tabela 2: Kontrolni faktorji in njihovi nivoji

\begin{tabular}{|l|c|c|c|}
\hline \multicolumn{1}{|c|}{ Control factors } & Level 1 & Level 2 & Level 3 \\
\hline Cutting speed, $V /(\mathrm{m} / \mathrm{min})$ & 100 & 120 & 140 \\
\hline Feed rate, $f /(\mathrm{mm} / \mathrm{r})$ & 0.04 & 0.06 & 0.08 \\
\hline Machined part number, $M P$ & 4 & 8 & 12 \\
\hline
\end{tabular}

ANOVA was used to find the relative contribution of the cutting conditions in controlling the response of a turning operation. The optimum combination of the

Table 3: Experimental results and corresponding $S / N$ ratios

Tabela 3: Rezultati preizkusov in odgovarjajoča razmerja $S / N$

\begin{tabular}{|c|c|c|c|c|c|c|c|c|c|}
\hline \multirow{2}{*}{ Run } & \multicolumn{3}{|c|}{ Control factors } & \multicolumn{3}{c|}{ Experimental results } & \multicolumn{3}{c|}{ Signal-to-noise ratio $(S / N)$} \\
\cline { 2 - 10 } & $V$ & $f$ & $M P$ & $I D e$ & $R_{\mathrm{a}}$ & $R$ & $R$ & $R_{\mathrm{a}}$ & $I D e$ \\
\hline 1 & 120 & 0.04 & 4 & 0.016 & 0.164 & 3.33 & -10.448 & 15.703 & 35.917 \\
\hline 2 & 120 & 0.06 & 8 & 0.012 & 0.293 & 3.04 & -9.657 & 10.662 & 38.416 \\
\hline 3 & 120 & 0.08 & 12 & 0.011 & 0.459 & 3.21 & -10.130 & 6.763 & 39.172 \\
\hline 4 & 140 & 0.04 & 12 & 0.010 & 0.176 & 2.63 & -8.389 & 15.089 & 40.000 \\
\hline 5 & 140 & 0.06 & 4 & 0.008 & 0.178 & 3.02 & -9.600 & 14.991 & 41.938 \\
\hline 6 & 140 & 0.08 & 8 & 0.005 & 0.363 & 2.35 & -7.421 & 8.801 & 46.020 \\
\hline 7 & 160 & 0.04 & 8 & 0.010 & 0.271 & 4.23 & -12.526 & 11.340 & 40.000 \\
\hline 8 & 160 & 0.06 & 12 & 0.013 & 0.342 & 4.6 & -13.255 & 9.319 & 37.721 \\
\hline 9 & 160 & 0.08 & 4 & 0.007 & 0.363 & 4.51 & -13.083 & 8.801 & 43.098 \\
\hline
\end{tabular}


control factors for the surface roughness, diameter error and roundness was determined with the ANOVA table and $S / N$ ratios. Lastly, confirmation tests were done using the optimum cutting conditions found with the Taguchi optimization method and thereby the validity of the optimization was tested.

\section{RESULTS AND DISCUSSION}

The surface roughness, the inner-diameter error and the roundness achieved during the hard turning of innerbearing rings were measured after the experiments performed according to the L9 orthogonal array. The lowest values of the surface roughness, the inner-diameter error and the roundness significantly improve the quality of the bearing assembly. For this reason, the lower-the-better quality characteristic was used for the calculation of the $S / N$ ratio. The experimental results and $S / N$ ratios are given in Table 3.

\subsection{Evaluation of the surface roughness for an inner ring bore}

The interaction plots for the surface-roughness parameters are given in Figure 2. The minimum value of the surface roughness $\left(R_{\mathrm{a}}\right)$ was obtained for $V=120 \mathrm{~m} / \mathrm{min}$, $f=0.04 \mathrm{~mm} / \mathrm{r}$ and the $4^{\text {th }}$ machined part. It can be seen from Figure 2 that the $R_{\mathrm{a}}$ value increases as the feed rate is increased from $0.04 \mathrm{~mm} / \mathrm{r}$ to $0.08 \mathrm{~mm} / \mathrm{r}$ when hard turning the inner-bearing ring bores. With the raise in the feed-rate value from $0.04 \mathrm{~mm} / \mathrm{r}$ to $0.08 \mathrm{~mm} / \mathrm{r}$, a significant increase is observed in the $R_{\mathrm{a}}$ value. No significant relation between the surface roughness and the number of the machined ring bore is seen.

The $S / N$ ratios of the $R_{\mathrm{a}}$ data obtained from the experimental results, used to determine the optimum level of each variable, were calculated according to Equation (1). Figure 3 illustrates the plots of the $S / N$ ratios that were calculated for $R_{\mathrm{a}}$ in the hard turning of the inner ring bores. The $S / N$ ratios of the factors for each level are shown in Table 4 . Different values $(\Delta)$ of the $S / N$ ratio between the maximum and the minimum

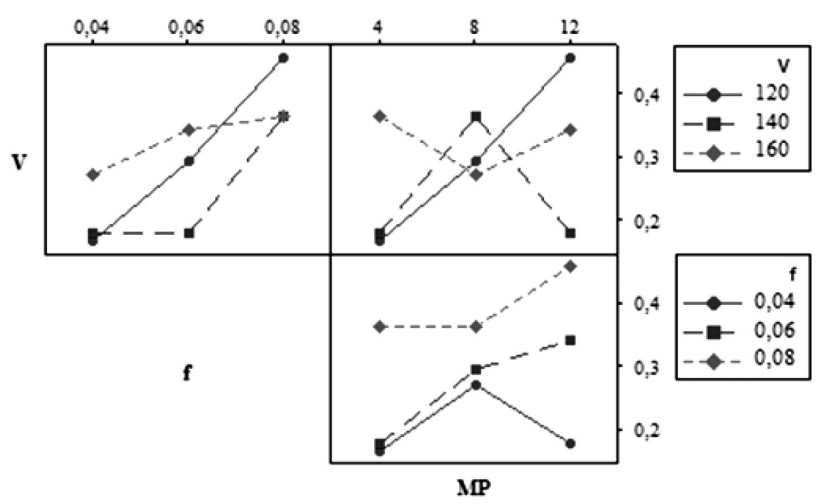

Figure 2: Interaction plots for surface roughness Slika 2: Interakcijski diagrami za hrapavost površine

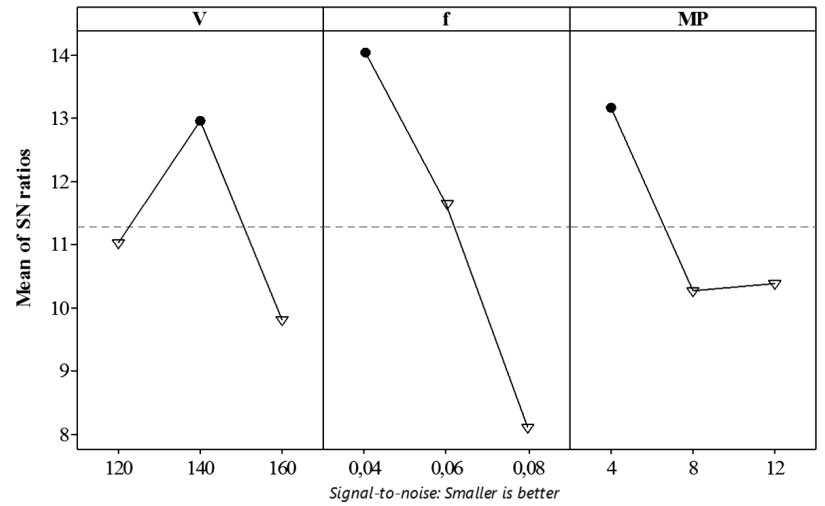

Figure 3: Main-effect plot for surface roughness Slika 3: Diagram glavnega učinka na hrapavost površine

are also shown in Table 4. Therefore, by considering the $S / N$ ratios in Table 4 and Figure 3, the optimum cutting conditions for the surface roughness were $V 2(V=140$ $\mathrm{m} / \mathrm{min}), f 1(f=0.04 \mathrm{~mm} / \mathrm{r})$ and $M P 1$ (the $4^{\text {th }}$ machined part). The smallest surface roughness and its $S / N$ ratio that can be obtained with these levels were calculated using Equations (2) and (3). The $R_{\mathrm{a}}$ value and its $S / N$ ratio were determined as $0.131 \mu \mathrm{m}$ and $17.621 \mathrm{~dB}$, respectively:

$$
\begin{gathered}
\eta_{\mathrm{G}}=\bar{\eta}_{\mathrm{G}}+\left(\bar{V}_{0}-\bar{\eta}_{\mathrm{G}}\right)+\left(\bar{f}_{0}-\bar{\eta}_{\mathrm{G}}\right)+\left(\bar{M} \bar{P}_{0}-\bar{\eta}_{\mathrm{G}}\right) \\
R_{a_{\text {cal }}}=10^{-\frac{\eta_{\mathrm{G}}}{20}}
\end{gathered}
$$

In these equations, $\eta_{\mathrm{G}}$ is the $S / N$ ratio calculated at the optimum levels $(\mathrm{dB}), \eta_{\mathrm{G}}$ is the average $S / N$ ratio of all the variables $(\mathrm{dB}), \bar{V}_{0}, \bar{f}_{0}, \bar{M} \bar{P}_{0}$ are the mean $S / N$ ratios when factors $V, f$ and $M P$ are at the optimum levels $(\mathrm{dB})$, and $R_{\mathrm{a}}$ cal is the calculated surface-roughness $\left(R_{\mathrm{a}}\right)$ value.

Table 4: Response table of $S / N$ ratios for surface roughness Tabela 4: Tabela odzivov razmerja $S / N$ glede na hrapavost površine

\begin{tabular}{|c|c|c|c|c|c|}
\hline \multirow{2}{*}{ Factor } & \multicolumn{4}{|c|}{$S / N$ ratio } & \multirow{2}{*}{ Rank } \\
\cline { 2 - 5 } & Level 1 & Level 2 & Level 3 & $\Delta$ & \\
\hline$V$ & 11.043 & 12.961 & 9.821 & 3.14 & 2 \\
\hline$f$ & 14.044 & 11.658 & 8.122 & 5.922 & 1 \\
\hline$M P$ & 13.166 & 10.268 & 10.391 & 2.897 & 3 \\
\hline
\end{tabular}

The analysis of variance (ANOVA) was used to find which design parameters significantly affect the surface roughness. This analysis was carried out at the $95 \%$ confidence level. The ANOVA results for the surface roughness $\left(R_{\mathrm{a}}\right)$ are shown in Table 5. This table also shows the degree of freedom $(D F)$, the sum of squares $(S S)$, the mean square $(M S)$, the $F$-values $(F)$, the probability $(P)$ and the percentage-contribution ratio $(P C R)$ of each factor. A low $P$-value of 0.05 shows a statistically significant level of the source for the corresponding response. The $F$-ratios and their $P C R$ were taken into consideration to identify the significance levels of the variables. Table 5 indicates that the most effective variable for the $R_{\mathrm{a}}$ 
value is the feed rate with the PCR of $62.84 \%$. It is well known that the theoretical geometrical-surface roughness is primarily a function of the feed for a given nose radius and that it changes with the square of the feed-rate value. It is once again shown that the feed rate has an important effect on the surface roughness in hard turning. The other variables having an effect on $R_{\mathrm{a}}$ are the number of the machined part with a $P C R$ of $19.00 \%$ and the cutting speed with a $P C R$ of $17.74 \%$.

Table 5: ANOVA for $S / N$ ratios for surface roughness

Tabela 5: ANOVA za $S / N$-razmerje glede na hrapavost površine

\begin{tabular}{|c|c|c|c|c|c|c|}
\hline Source & $D F$ & $S S$ & $M S$ & $F$ & $P$ & $P C R$ \\
\hline$V$ & 2 & 15.0351 & 7.5176 & 42.42 & 0.023 & 17.74 \\
\hline$f$ & 2 & 53.265 & 26.6325 & 150.28 & 0.007 & 62.84 \\
\hline$M P$ & 2 & 16.1066 & 8.0533 & 45.44 & 0.022 & 19.00 \\
\hline Error & 2 & 0.3544 & 0.1772 & & & 0.42 \\
\hline Total & 8 & 84.7612 & & & & 100 \\
\hline
\end{tabular}

\subsection{Evaluation of the roundness for an inner ring bore}

The interaction plots for the roundness and the cutting conditions are given in Figure 4. The minimum value of the roundness was obtained at $V=140 \mathrm{~m} / \mathrm{min}$ and $f=0.08 \mathrm{~mm} / \mathrm{r}$ for the $8^{\text {th }}$ machined part. The roundness is generally affected by the cutting parameters such as the cutting speed, the feed rate and the depth of cut. In Figure 4 the roundness decreases for all the feed rates with the cutting speed increasing from $120 \mathrm{~m} / \mathrm{min}$ to 140 $\mathrm{m} / \mathrm{min}$. This can be attributed to the cutting force decrease with the increasing cutting speed. This decrease is explained with a thermal softening of the machined material in the flow zone due to the increasing cutting temperature. The highest roundness values for all the feed rates were obtained at a cutting speed of $160 \mathrm{~m} / \mathrm{min}$. Although a moderate increase in the cutting speed decreases the cutting force, a further increase in the cutting speed was thought to increase the tool wear. This, in turn, increases the roundness. In addition to the cutting parameters, the roundness is also affected by other factors such as the clamping system and the machinetool rigidity.

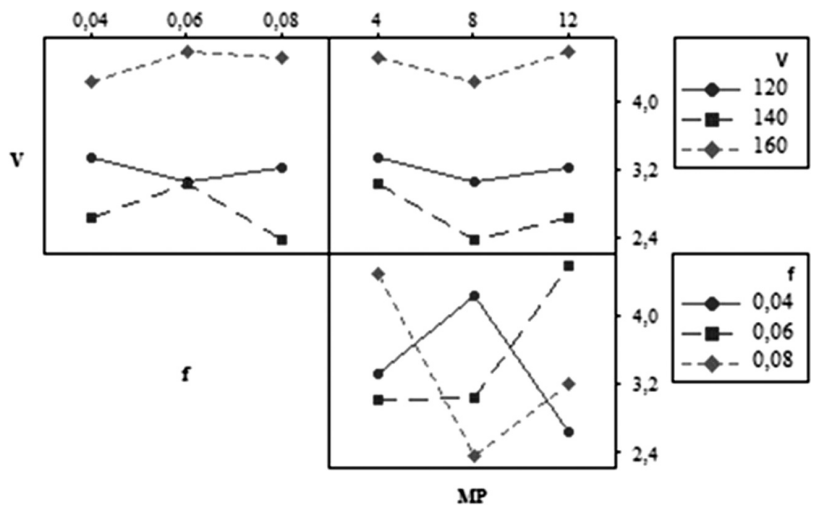

Figure 4: Interaction plots for roundness

Slika 4: Diagrami medsebojnih vplivov na okroglost
The experimental results and the calculated $S / N$ ratios for the roundness are given Table 3. The $S / N$ ratios of the factors for each level are shown in Table 6. The values in Table 6 are given as the plots from Figure 5. It is seen from Figure 5 and Table $\mathbf{6}$ that the control factors can be used to reach the smallest roundness in the machining of inner ring bores. The smallest roundness is obtained in the following cutting conditions: $V 2, f 3$ and $M P 2$. The optimum cutting conditions for the roundness were $V 2(V=140 \mathrm{~m} / \mathrm{min}), f 3(f=0.08 \mathrm{~mm} / \mathrm{r})$ and $M P 2$ (the $8^{\text {th }}$ machined part). The $S / N$ ratios for the roundness of $R_{\text {cal }}$ were calculated with Equation (3). Consequently, $\eta_{\mathrm{G}}$ and $R_{\text {cal }}$ calculated for the optimum cutting conditions were found to be $-7.5487 \mathrm{~dB}$ and $2.38 \mu \mathrm{m}$, respectively.

Table 6: Response table of $S / N$ ratios for roundness

Tabela 6: Tabela odgovorov $S / N$-razmerje glede na okroglost

\begin{tabular}{|c|c|c|c|c|c|}
\hline \multirow{2}{*}{ Symbol } & \multicolumn{4}{|c|}{$S / N$ ratio } & \multirow{2}{*}{ Rank } \\
\cline { 2 - 5 } & Level 1 & Level 2 & Level 3 & $\Delta$ & \\
\hline$V$ & -10.079 & -8.474 & -12.955 & 4.482 & 1 \\
\hline$f$ & -10.458 & -10.838 & -10.212 & 0.626 & 3 \\
\hline$M P$ & -11.044 & -9.869 & -10.595 & 1.176 & 2 \\
\hline
\end{tabular}

Table 7: ANOVA for $S / N$ ratios for roundness

Tabela 7: ANOVA za $S / N$-razmerje glede na okroglost

\begin{tabular}{|c|c|c|c|c|c|c|}
\hline Source & $D F$ & $S S$ & $M S$ & $F$ & $P$ & $P C R$ \\
\hline$V$ & 2 & 30.9353 & 15.4676 & 110.12 & 0.009 & 91.18 \\
\hline$f$ & 2 & 0.5965 & 0.2982 & 2.12 & 0.320 & 1.76 \\
\hline$M P$ & 2 & 2.1115 & 1.0558 & 7.52 & 0.117 & 6.23 \\
\hline Error & 2 & 0.2809 & 0.1405 & & & 0.83 \\
\hline Total & 8 & 33.9242 & & & & 100 \\
\hline
\end{tabular}

The ANOVA results for the inner-ring-bore roundness are given in Table 7 . The $F$-ratios and their PCRs were taken into consideration to identify the significance level of the variables. Table 7 shows that the most effective variable for the roundness is the cutting speed with a $P C R$ of $91.18 \%$. The contributions of the number of the machined part and the feed rate were found to be $6.23 \%$ and $1.76 \%$, respectively. Consequently, the feed rate and the number of the machined part do not have significant

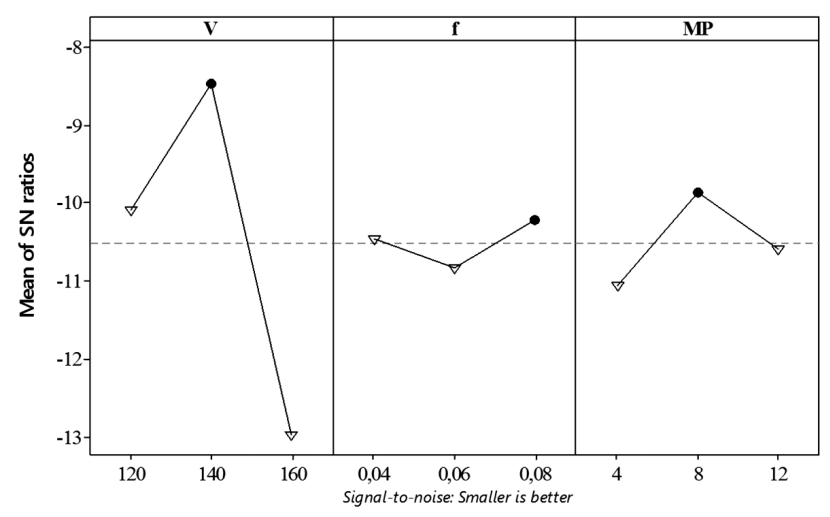

Figure 5: Main-effect plots for roundness

Slika 5: Diagrami glavnih vplivov na okroglost 


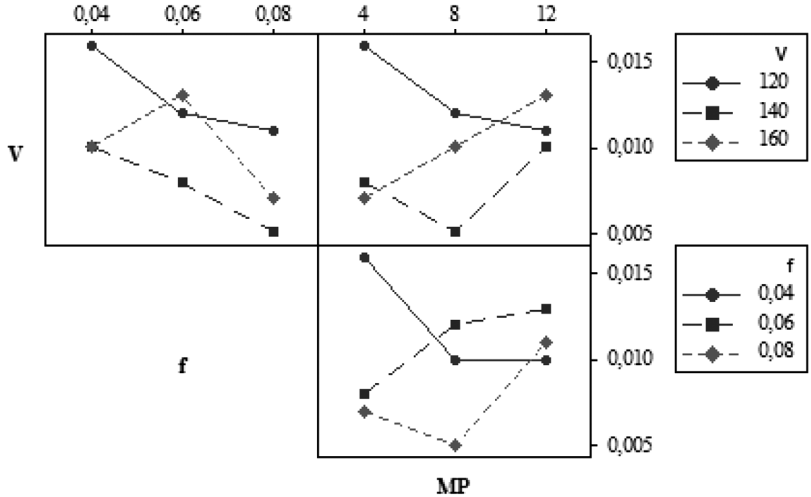

Figure 6: Interaction plots for inner-diameter error Slika 6: Interakcijski diagrami za napako notranjega premera

effects on the roundness $(P<0.05)$. The error ratio was calculated as $0.83 \%$ and it is the smallest ratio.

\subsection{Evaluation of the inner-ring-bore-diameter error}

The interaction plots for the inner-diameter error and the cutting conditions are given in Figure 6. The minimum value of the inner-diameter error was obtained at $V=140 \mathrm{~m} / \mathrm{min}$ and $f=0.08 \mathrm{~mm} / \mathrm{r}$ for the $8^{\text {th }}$ machined part. The cutting speed might have influenced the resulting cutting forces and this interaction might have consequently influenced the diameter error in a number of ways, i.e., by changing the elastic deformation of the workpiece, by altering the tool wear, by increasing the thermal distortion, by forming a built-up edge (BUE) and by increasing the radial-spindle error. In this case, the most likely cause for the change in the diameter error is considered to be the change in the elastic deformation of the workpiece.

The experimental results and the calculated $S / N$ ratios for the roundness are given Table 3. Figure 7 shows the plots of the $S / N$ ratios that were calculated for the inner-diameter error. The $S / N$ ratios of the factors for each level are shown in Table $\mathbf{8}$. Hence, by considering the $S / N$ ratios from Table 8 and Figure 7, the optimum cutting conditions for the inner-diameter error were $V 2$ $(V=140 \mathrm{~m} / \mathrm{min}), f 3(f=0.08 \mathrm{~mm} / \mathrm{r})$ and $M P 2$ (the $8^{\text {th }}$

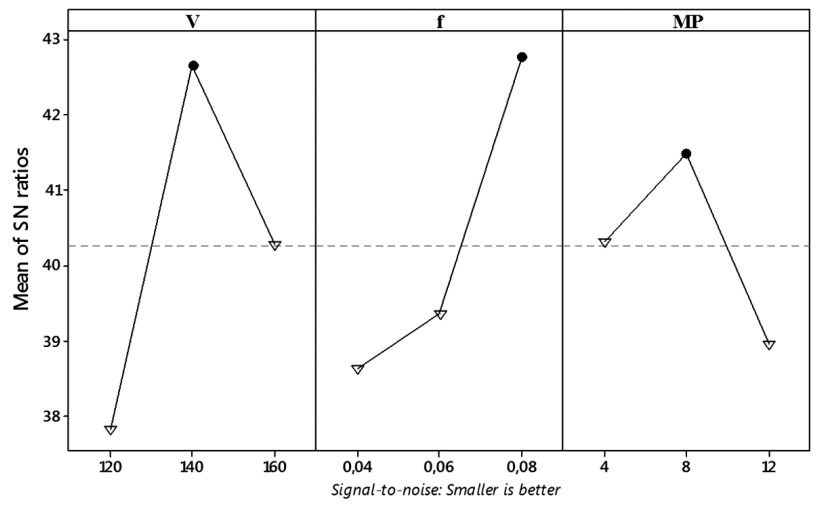

Figure 7: Main-effect plots for inner-diameter error

Slika 7: Diagrami glavnih učinkov na napako notranjega premera machined part). The $S / N$ ratios for the roundness of IDe (the inner diameter error) were calculated with Equation (3). Consequently, $\eta_{\mathrm{G}}$ and $I D e_{\text {cal }}$ calculated for the optimum cutting conditions were found to be $46.388 \mathrm{~dB}$ and $0.0048 \mu \mathrm{m}$, respectively.

Table 8: Response table of $S / N$ ratios for inner-diameter error Tabela 8: Tabela odgovorov razmerja $S / N$ glede na napako notranjega premera

\begin{tabular}{|c|c|c|c|c|c|}
\hline \multirow{2}{*}{ Symbol } & \multicolumn{4}{|c|}{ Mean S/N ratio } & \multirow{2}{*}{ Rank } \\
\cline { 2 - 5 } & Level 1 & Level 2 & Level 3 & $\Delta$ & \\
\hline$V$ & 37.84 & 42.65 & 40.27 & 4.82 & 1 \\
\hline$f$ & 38.64 & 39.36 & 42.76 & 4.12 & 2 \\
\hline$M P$ & 40.32 & 41.48 & 38.96 & 2.51 & 3 \\
\hline
\end{tabular}

Table 9: ANOVA for $S / N$ ratios for inner-diameter error Tabela 9: ANOVA za $S / N$-razmerje glede na napako notranjega premera

\begin{tabular}{|c|c|c|c|c|c|c|}
\hline Source & $D F$ & $S S$ & $M S$ & $F$ & $P$ & $P C R$ \\
\hline$V$ & 2 & 34.815 & 17.4075 & 54.87 & 0.018 & 46.99 \\
\hline$f$ & 2 & 29.1223 & 14.5612 & 45.9 & 0.021 & 39.32 \\
\hline$M P$ & 2 & 9.5031 & 4.7515 & 14.98 & 0.063 & 12.83 \\
\hline Error & 2 & 0.6344 & 0.3172 & & & 0.86 \\
\hline Total & 8 & 74.0748 & & & & 100 \\
\hline
\end{tabular}

The ANOVA results for the inner-diameter error are shown in Table 9. The $F$-ratios from Table 9 and their $P C R$ were taken into consideration to identify the significance levels of the variables. Table 9 shows that the most effective variable for the inner-diameter error is the cutting speed with a PCR of $46.99 \%$. The feed rate and the number of the machined part also affect the innerdiameter error with their PCR being 39.32 and $12.83 \%$, respectively. Therefore, the number of the machined part does not have a significant effect on the inner-diameter error $(P<0.05)$. As the $P$-value of the number of the machined part is less than 0.05 , it is not significant.

\subsection{Confirmation tests}

Confirmation tests of the control factors were made for the Taguchi method. The optimization was verified with the confirmation tests after the determination of the control factors that give the optimum results. The confirmation tests were conducted at the optimum factor levels for each surface roughness, roundness and diameter error. The confirmation tests performed at the optimum variable levels determined for the surface roughness, the roundness and the inner-diameter error were evaluated by taking into consideration the confidence interval $(C I)$ calculated with Equations (4) and (5) ${ }^{16,17}$ :

$$
\begin{gathered}
C I=\sqrt{F_{0.05}\left(1, v_{\mathrm{e}}\right) V_{\mathrm{e}}\left(\frac{1}{n_{\mathrm{eff}}}+\frac{1}{r}\right)} \\
n_{\mathrm{eff}}=\frac{N}{1+v_{\mathrm{T}}}
\end{gathered}
$$


where $v_{\mathrm{e}}$ is the error degree of freedom, $V_{\mathrm{e}}$ is the error variance, $n_{\mathrm{eff}}$ is the repeating number of the experiments, $N$ is the total number of the experiments, $v_{\mathrm{T}}$ is the variable's degree of freedom and $r$ is the number of the confirmation tests.

Table 10 gives a comparison of the results of the confirmation tests conducted according to the optimum levels of the variables and the values calculated using Equations (2) and (3). Besides, confidence-interval values for $R_{\mathrm{a}}, R$ and IDe were calculated using Equations (4) and (5).

Table 10: Comparison between confirmatory test results and calculated values

Tabela 10: Primerjava med rezultati potrditvenih preizkusov in izračunanimi vrednostmi

\begin{tabular}{|c|c|c|c|c|c|}
\hline \multicolumn{2}{|c|}{$\begin{array}{c}\text { Confirmatory } \\
\text { experiment results }\end{array}$} & \multicolumn{2}{c|}{ Calculated values } & \multicolumn{2}{c|}{ Differences } \\
\hline$R_{\mathrm{a} \text { mea }} / \mu \mathrm{m}$ & mea $/ \mathrm{dB}$ & $R_{\mathrm{a} \mathrm{cal}} / \mu \mathrm{m}$ & $\eta_{\text {cal }} / \mathrm{dB}$ & $\begin{array}{c}R_{\mathrm{a} \text { mea }}- \\
R_{\mathrm{a} \text { cal }}\end{array}$ & $\eta_{\text {mea }}-\eta_{\text {cal }}$ \\
\hline 0.151 & 16.42 & 0.131 & 17.621 & 0.02 & 1.201 \\
\hline$R_{\text {mea }} / \mu \mathrm{m}$ & $\eta_{\text {mea }} / \mathrm{dB}$ & $R_{\mathrm{cal}} / \mu \mathrm{m}$ & $\eta_{\mathrm{cal}} / \mathrm{dB}$ & $\begin{array}{c}R_{\text {mea }}- \\
R_{\text {cal }}\end{array}$ & $\eta_{\text {mea }}-\eta_{\text {cal }}$ \\
\hline 2.35 & -7.4214 & 2.38 & -7.5487 & 0.03 & 0.1273 \\
\hline$I D e_{\text {mea }} / \mu \mathrm{m}$ & $\eta_{\text {mea }} / \mathrm{dB}$ & $I D e_{\text {cal }} / \mu \mathrm{m}$ & $\eta_{\text {cal }} / \mathrm{dB}$ & $\begin{array}{c}I D e_{\text {mea }}- \\
I D e_{\text {cal }}\end{array}$ & $\eta_{\text {mea }}-\eta_{\text {cal }}$ \\
\hline 0.005 & 46.020 & 0.0048 & 46.388 & 0.0002 & 0.368 \\
\hline
\end{tabular}

Using Equation (5), confidence values of (2.56, 2.28 and 3.42) $\mathrm{dB}$ were obtained for the surface roughness $\left(R_{\mathrm{a}}\right)$, the roundness $(R)$ and the inner-diameter error (IDe), respectively. Table 10 shows differences between the values obtained with the confirmatory tests and the values of the $S / N$ ratios calculated with Equations (2) and (3). It is seen that a difference of $1.201 \mathrm{~dB}$ is under the $5 \%$ confidence interval for the surface roughness of 2.56 $\mathrm{dB}$, a difference of $0.1273 \mathrm{~dB}$ is under the $5 \%$ confidence interval of for the roundness of $2.28 \mathrm{~dB}$ and, similarly, a difference of $0.368 \mathrm{~dB}$ is under the $5 \%$ confidence interval for the inner-diameter error of $3.42 \mathrm{~dB}$. Therefore, the optimum-control-factor settings for all the cutting conditions were confirmed as confident.

\section{CONCLUSIONS}

In this study, the cutting conditions for the surface roughness, the inner-diameter error and the roundness during the hard turning of an inner ring bore were optimized with the Taguchi method. The results obtained from this study are presented below:

According to the results of the statistical analysis, it was found that the feed rate was the most significant factor for the surface roughness with a PCR of $62.84 \%$. The cutting speed was the most significant parameter for the roundness and the inner-diameter error with $P R C$ of 91.18 and $46.99 \%$, respectively.

The optimum levels of the control factors for minimizing the surface roughness, the roundness and the inner-diameter error using $S / N$ ratios were determined.
The optimum conditions for the surface roughness were observed at $V 2-f 1-M P 1$ (i.e., cutting speed $V=140$ $\mathrm{m} / \mathrm{min}$, feed rate $f=0.04 \mathrm{~mm} / \mathrm{r}$ and the $4^{\text {th }}$ machined part). The optimum conditions for the roundness and the inner-diameter error were observed at the same levels, $V 2-f 3-M P 2$ (i.e., cutting speed $V=140 \mathrm{~m} / \mathrm{min}$, feed rate $f$ $=0.08 \mathrm{~mm} / \mathrm{r}$ and the $8^{\text {th }}$ machined part).

Confirmation tests were carried out at the optimum conditions. According to the confirmation-test results, the measured values were found to be within the $95 \%$ confidence interval.

The outcomes for the roundness and the inner-diameter errors are very close to the predicted values. Thus, there is no need to carry out confirmation tests if the cutting conditions found with the optimization procedure are included in the cutting conditions within the Taguchi experimental design.

\section{Acknowledgement}

The authors would like to thank the Ministry of Science, Industry and Technology, Turkey (00980.STZ. 2011-2) and ORS Bearings, Turkey, for the financial support of this study.

\section{REFERENCES}

${ }^{1}$ H. K. Tönshoff, C. Arendt, R. B. Amor, Cutting of hardened steel, Annals of the CIRP, 49 (2000) 2, 547-566, doi:10.1016/S00078506(07)63455-6

${ }^{2}$ G. Byrne, D. Dornfeld, B. Denkena, Advancing cutting technology, Annals of the CIRP, 52 (2003) 2, 483-507, doi:10.1016/S0007c8506(07)60200-5

${ }^{3}$ W. König, A. Berktold, K. F. Koch, Turning versus grinding - a comparison of surface integrity aspects and attainable accuracies, Annals of the CIRP, 42 (1993) 1, 39-43, doi:10.1016/S0007-8506(07) 62387-7

${ }^{4}$ F. Klocke, E. Brinksmeier, K. Weinert, Capability profile of hard cutting and grinding processes, Annals of the CIRP, 54 (2005) 2, 22-45, doi:10.1016/S0007-8506(07)60018-3

${ }^{5}$ M. N. Islam, Effect of additional factors on dimensional accuracy and surface finish of turned parts, Machining Science and Technology: An International Journal, 17 (2013) 1, 145-162, doi:10.1080/ 10910344.2012.747936

${ }^{6}$ N. H. Rafai, M. N. Islam, An investigation into dimensional accuracy and surface finish achievable in dry turning, Machining Science and Technology: An International Journal, 13 (2009) 4, 571-589, doi:10.1080/10910340903451456

${ }^{7}$ J. A. Malluck, S. N. Melkote, Modeling of deformation of ring shaped workpieces due to chucking and cutting forces, Journal of Manufacturing Science and Engineering, 126 (2004), 141-147, doi:10.1115/1.1643079

${ }^{8}$ E. Brinksmeier, J. Sölter, C. Grote, Distortion engineering - identification of causes for dimensional and form deviations of bearing rings, CIRP Annals - Manufacturing Technology, 56 (2007) 1, 109-112, doi:10.1016/j.cirp.2007.05.028

${ }^{9}$ L. Björn, T. Beekhuis, E. Brinksmeier, M. Garbrecht, J. Sölter, Improving the shape quality of bearing rings in soft turning by using a Fast Tool Servo, Prod. Eng. Res. Devel., 3 (2009), 469-474, doi:10.1007/s11740-009-0175-Z 
${ }^{10}$ E. Brinksmeier, J. Sölter, Prediction of shape deviations in machining, CIRP Annals - Manufacturing Technology, 58 (2009) 1 , 507-510, doi:10.1016/j.cirp.2009.03.123

${ }^{11}$ D. Stöbener, B. Beekhuis, Application of an in situ measuring system for the compensation of wall thickness variations during turning of thin-walled rings, CIRP Annals - Manufacturing Technology, 62 (2013) 1, 511-514, doi:10.1016/j.cirp.2013.03.129

${ }^{12}$ J. M. Zhou, M. Andersson, J. E. Stahl, Identification of cutting errors in precision hard turning process, Journal of Materials Processing Technology, 153-154 (2004), 746-750, doi:10.1016/j.jmatprotec. 2004.04.331

${ }^{13}$ J. Sölter, C. Grote, E. Brinksmeier, Influence of clamping strategies on roundness deviations of turned rings, Machining Science and Technology, 15 (2011), 338-355, doi:10.1080/10910344.2011. 601207
${ }^{14}$ K. Bouacha, M. A. Yallese, T. Mabrouki, J. F. Rigal, Statistical anal ysis of surface roughness and cutting forces using response surface methodology in hard turning of AISI 52100 bearing steel with CBN tool, Int. J. Refract. Met. Hard., 28 (2010) 3, 349-361, doi:10.1016/ j.ijrmhm.2009.11.011

${ }^{15}$ P. G. Benardos, G. C. Vosniakos, Predicting surface roughness in machining: A review, International Journal of Machine Tools \& Manufacture, 43 (2003) 8, 833-844, doi:10.1016/S0890-6955(03) 00059-2

${ }^{16}$ M. Gunay, E. Yucel, Application of Taguchi method for determining optimum surface roughness in turning of high-alloy white cast iron, Measurement, 46 (2013), 913-919, doi:10.1016/j.measurement.2012. 10.013

${ }^{17}$ E. Yucel, M. Gunay, Modelling and optimization of the cutting conditions in hard turning of high-alloy white cast iron (Ni-Hard), Proc. IMechE, Part C: J. Mechanical Engineering Science, 227 (2013) 10, 2280-2290, doi:10.1177/0954406212471755 